\title{
Impact Assessment of Cluster Front Line Demonstration on Rapeseed Crop in Darrang District of Assam, India
}

\author{
Rinku Moni Phukon ${ }^{*}$, Bipul Kumar Das ${ }^{2}$, \\ Rizwanul Helim $^{3}$ and Pabitra Kumar Bordoloi ${ }^{4}$
}

\author{
${ }^{1}$ Horticultural Research Station, Kahikuchi-781017, Assam Agricultural University, \\ Kahikuchi, Assam, India \\ ${ }^{2}$ Krishi Vigyan Kendra, AAU, Dhubri-783348, Assam Agricultural University, Assam, India \\ ${ }^{3}$ Krishi Vigyan Kendra, Assam Agricultural University, Kamrup, Assam, India 781017, India \\ ${ }^{4}$ Regional Agricultural Research Station, Assam agricultural University, \\ Shillongani, Assam, India 782002 \\ *Corresponding author
}

\section{A B S T R A C T}

\begin{tabular}{|l|}
\hline Ke y w o r d s \\
$\begin{array}{l}\text { Rapeseed, Yield, } \\
\text { High yielding } \\
\text { variety, CFLD }\end{array}$ \\
\hline Article Info \\
\hline $\begin{array}{l}\text { Accepted: } \\
\text { 15 August } 2020 \\
\text { Available Online: } \\
\text { 10 September } 2020\end{array}$ \\
\hline
\end{tabular}

Rapeseed is one of the most important oilseeds crop in Assam, which plays a major role in enhancement the income of marginal and small farmers of Darrang district. One of the major constraints of low productivity of rapeseed farming is using of local varieties. However, delayed sowing \& use of higher seed rate resulting into dense plant population, uneven plant population, uncontrolled weeds, ignorance about recommended doses of fertilizers and lack of plant protection measures were the predominant identified causes of low productivity of oilseeds in the district .To replace this problem, Krishi Vigyan Kendra, Darrang conducted Cluster Front Line Demonstration (CFLD) on high yielding rapeseed varieties viz; TS -38 and TS-46 during two consecutive years from 2016-17 to 2017-18. Cultivation of high yielding rapeseed varieties showed percentage increase of 29.17 and 50.8 respectively over local check. The yield under demonstration plots were 7.75 (TS-38) and 8.75 (TS -46) q /ha as compared to 6.0 and $5.8 \mathrm{q} /$ ha respectively in farmer's practices.

\section{Introduction}

Rapeseed and mustard are the third most important edible oilseed crops of the world after soybean and oil palm. This crop accounts for nearly one-third of the oil produced in India, making it the country's key edible oilseed crop. Being a major rabi (winter season) oilseed crop in India and having an advantage of soil moisture conserved during monsoon, it has greater potential to increase the availability of edible oil from the domestic production. About 90 per cent of the total edible oil produced in the country comes from two oil seed crops namely rapeseed-mustard and groundnut. In India, rape seed mustard is an important source of edible oil followed by ground nut (Panday et al., 1999). India account for $19.8 \%$ and $9.8 \%$ of the total acerage and production (USDA). During the last eight years, there has been a considerable increase in productivity 
from $1840 \mathrm{~kg} / \mathrm{ha}$ in $2010-11$ to $1980 \mathrm{~kg} / \mathrm{ha}$ in 2018-19 and production has also increased from $61.64 \mathrm{mt}$ in $2010-11$ to $72.42 \mathrm{mt}$ in 2018 19 (ICAR, DRMR). The Cluster Front Line Demonstration (CFLD) is an applied approach to accelerate the dissemination of proven \& tested technologies at farmer's fields in a participatory mode with an objective to explore the maximum available resources of crop production and also to bridge the productivity gaps by enhancing the production. Therefore, KVKs are being emphasized to organize large scale CFLD programs on oilseed crops for harnessing its productivity potential.

\section{Materials and Methods}

Krishi Vigyan Kendra (KVK) has conducted 149 Cluster Front Line Demonstrations on rapeseed crop in farmer's field in different blocks of Darrang district during 2016-17 and 2017-18. For conducting CFLDs, farmers were selected following the survey suggested by Choudhary (1999).The required inputs were supplied and regular visits to the demonstration fields by the KVK scientists ensured with proper guidance to the farmers. Trainings, group meetings and Field days were also organized to provide the opportunities for other farmers of neighboring village to witness the benefits of demonstrated technologies. The sowing was done during first week of October under assured irrigated conditions (STWs) and harvested during first fortnight of March. However, the practices followed by farmers in general are use local cultivar (M-27), seed rate @ 10-12 kg/ha, no seed treatment, sowing from last week of October to last week of November or after Sali paddy, no use of recommended doses of fertilizer, no irrigation and plant protection measures followed. Bee hives boxes were placed @ 5 nos./ha in all demonstrated plots to enhance pollination. The data output were collected from both CFLD plots as well as control plots and cost of cultivation, net income, and benefit cost ratio were also worked out (Samui et al., 2000).

The impact on yield was calculated by using following formula as given below

Impact on yield = Yield of demonstration plot (a/ha) - Yield of control plot ( q/ha) X100 (\% increase) Yield of control plot (qha)

\section{Package of practices followed by farmers under CFLD and in farmer's practice}

\begin{tabular}{|c|c|c|}
\hline Particulars & Technology Interventions & Farmer's practices \\
\hline Variety & TS 38, TS 46 & M-27 \\
\hline Seed rate & $10 \mathrm{~kg} / \mathrm{ha}$ & $10-12 \mathrm{~kg} / \mathrm{ha}$ \\
\hline Seed treatment & $\begin{array}{l}\text { Seed treatment with metalaxyl } 35 \mathrm{WS} @ 6 \mathrm{~g} / \mathrm{kg} \text { of } \\
\text { seed or Trichoderma @ } 810 \mathrm{gm} / \mathrm{kg} \text { seed }\end{array}$ & No use \\
\hline Time of sowing & Mid October- mid November & $\begin{array}{l}\text { Last week of October to last week of } \\
\text { November }\end{array}$ \\
\hline Method of sowing & Broadcasting and east west direction of sowing & $\begin{array}{l}\text { Broadcasting, no direction of } \\
\text { sowing methods }\end{array}$ \\
\hline Fertilizer application & 40:35:15 (N:P:K) kg/ha Borax @ 7.5 kg/ha & No proper dose \\
\hline Water management & $\begin{array}{l}\text { One irrigation of } 6 \mathrm{~cm} \text { depth of water may be } \\
\text { applied either at } 50 \% \text { flowering or at early siliqua } \\
\text { formation stage }\end{array}$ & No use \\
\hline Plant protection & $\begin{array}{l}\text { Need based application of immidachlopride @ } 0.5 \\
\mathrm{ml} / 1 \text { lt. of water for the management of aphid control }\end{array}$ & Indiscriminate use \\
\hline Inclusion of Bee hive & 5 honey bee colonies/ha & No use \\
\hline
\end{tabular}




\section{Results and Discussion}

Performances of Rapeseed var. TS- 38 \& TS46 were found to be substantially higher under the demonstration plots than under control during all the demonstration years (Table 1). The average yield of two varieties (TS- $38 \&$ TS- 46) were 7.75 and 8.75 q/ha during 2016-17 and 2017-18, respectively under CFLD plots however, under farmer's practices the average yield were 6.0 and 5.8 $\mathrm{q} /$ ha during respective years. However, the per cent increases against local yield were 29.17 and 50.8 during 2016-17 and 2017-18 respectively. The result is in conformity with the finding of Tiwari and Saxena (2001) and Tiwari et al., (2003) and Chaudhary et al., (2018). The results clearly indicated the positive effect of CFLDs over the existing practices toward enhancing the yield of rapeseed in the study area due to use of high yielding variety, timely sowing, balance doses of fertilizers along with boron, proper irrigation, need based plant protection and inclusion of honey bee colonies etc. The data of Table 2 reveals that the gross cost, net income and benefit cost ratio were Rs. 24500/ha, Rs. 14250/ha and 1.58 respectively during 2016-17 and Rs. 25700/ha, Rs. $18050 /$ ha and 1.7 , respectively during 2017 18 under demonstration plots. However, Rs. 22800/ha gross cost, Rs. 7200/ha net return with 1.32 benefit cost ratio during 2016-17 and Rs. 21969/ha gross cost, Rs. 7031/ha net return with 1.32 benefit cost ratio observed during 2017-18 under farmer's practices. The superiority of recommended package of practices under cluster frontline demonstration over farmers' practice was also reported by Singh et al., (2019) (Fig. 1).

\section{Figjure.1 Visit of NITI Aayog Team}

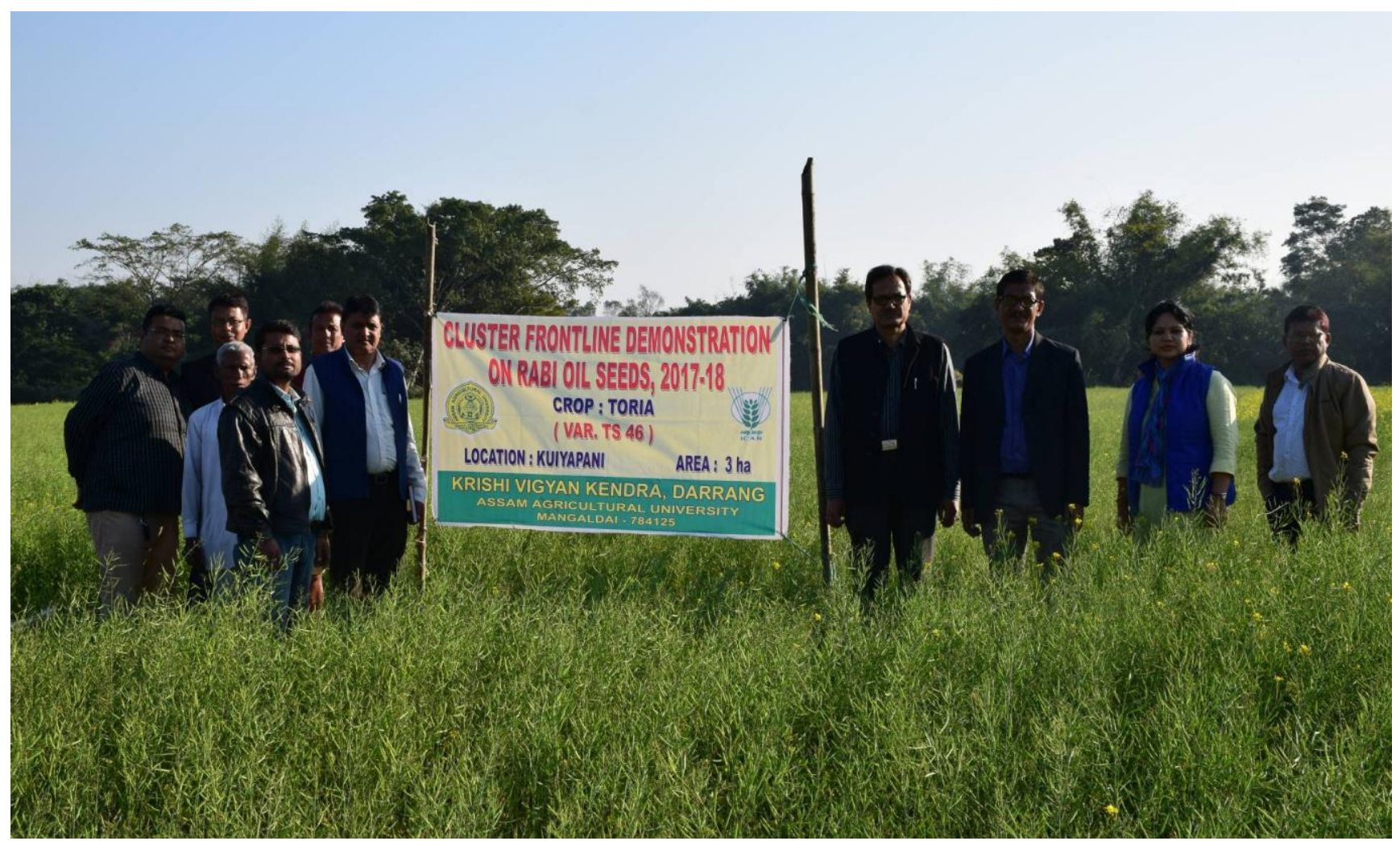


Table.1 Yield performance of rapeseed crop under CFLD

\begin{tabular}{|c|c|c|c|c|c|c|}
\hline \multirow[t]{2}{*}{ Varity } & \multirow[t]{2}{*}{ Year } & \multirow[t]{2}{*}{ Demonstrations } & \multirow{2}{*}{$\begin{array}{c}\text { Area } \\
\text { (ha.) }\end{array}$} & \multicolumn{2}{|c|}{ Avg. yield (Q/ha.) } & \multirow{2}{*}{$\begin{array}{c}\% \text { increase } \\
\text { in Avg. yield }\end{array}$} \\
\hline & & & & Demo. & Check & \\
\hline TS- 38 & 2016-17 & 24 & 20.0 & 7.75 & 6.0 & 29.17 \\
\hline TS-46 & 2017-18 & 125 & 50.0 & 8.75 & 5.8 & 50.8 \\
\hline
\end{tabular}

Table.2 Economic indicators of rapeseed crop under CFLD

\begin{tabular}{|l|c|c|c|c|c|c|c|c|c|}
\hline Varity & Year & \multicolumn{2}{c|}{$\begin{array}{c}\text { Gross expenditure } \\
\text { (Rs./ha.) }\end{array}$} & \multicolumn{2}{c|}{$\begin{array}{c}\text { Gross return } \\
\text { (Rs./Ha.) }\end{array}$} & \multicolumn{2}{c|}{$\begin{array}{c}\text { Net return } \\
\text { (Rs./Ha) }\end{array}$} & \multicolumn{2}{c|}{ B:C Ratio } \\
\hline & & Demo. & FP & Demo. & FP & Demo & FP & Demo. & FP \\
\hline TS- 38 & $2016-17$ & $24500 /-$ & $22800 /-$ & $38750 /-$ & $30000 /-$ & $14250 /-$ & $7200 /-$ & 1.58 & 1.32 \\
\hline TS-46 & $\mathbf{2 0 1 7 - 1 8}$ & $\mathbf{2 5 7 0 0 / -}$ & $\mathbf{2 1 9 6 9 / -}$ & $\mathbf{4 3 7 5 0 / -}$ & $\mathbf{2 9 0 0 0 / -}$ & $\mathbf{1 8 0 5 0 / -}$ & $\mathbf{7 0 3 1 / -}$ & $\mathbf{1 . 7}$ & $\mathbf{1 . 3 2}$ \\
\hline
\end{tabular}

The results of cluster front line demonstrations convincingly proved that the yield of rapeseed could be increased by 29.17 per cent to 50.8 per cent with the better technological intervention. These varieties may be popularized in this area by the extension agencies to bridge the higher extension gap. The use of new production technologies will substantially augment the income as well as the livelihood of small and marginal farmers. Therefore, it is suggested that policy maker may provide adequate financial support to frontline extension system for organizing CFLDs under the close supervision of agricultural scientists and extension professionals. This varietal replacement strategy through CFLDs may help to increase the productivity oilseed crops at micro, meso and macro level.

\section{References}

Choudhary, B.N. 1999. Krishi Vigyan Kendraguide for KVK managers. Publication, Division of Agril. Extn., ICAR, pp 73-78.

Chaudhary R. P, Choudhary Govind Kumar, Prasad R, Singh Rekha and Chaturvedi A. K.
2018. Impact Assessment of Front Line Demonstration on Mustard Crop. Int.J.Curr.Microbiol.App.Sci, Special Issue7: 4737-4742.

Panday. I. D, Basudeo Singh and J.N. Sachan. 1999. Brassica Hybrid research in India: status and prospects. Proceedings of the tenth international rape seed congress. Canberra, Australia.

Samui, S K, Maitra, S, Roy, DK, Mandal, A K and Saha, D. 2000. Evaluation of front line demonstration on groundnut. J Indian Soc Coastal Agric Res, 18: 180-183.

Singh J.B., Singh N.K. and Tripathy C.K. 2019. Impact Assessment of Cluster Front Line Demonstration on mustard crop in Sultanpur district of UP. Agricultural Sciences., 8(1) $2277-8160$.

Tiwari, K. B. and Saxena, A. (2001). Economic analysis of FLD of oilseed in chhindwara. Bhartya Krishi Anusandhan Patrika, 16 (3\&4): 185189.

Tiwari, K. B, Singh, Vinay and Parihar, P. (2003). Role of FLD in transfer of gram production technology. Maharastra J. Extn. Edu., 22 (1):19.

\section{How to cite this article:}

Rinku Moni Phukon, Bipul Das, Rizwanul Helim and Pabitra Kumar Bordoloi. 2020. Impact Assessment of Cluster Front Line Demonstration on Rapeseed Crop in Darrang District of Assam, India. Int.J.Curr.Microbiol.App.Sci. 9(09): 1728-1731.

doi: https://doi.org/10.20546/ijcmas.2020.909.214 